\title{
Shopping to Save the World? \\ Reclaiming Global Citizenship within Irish Universities
}

\begin{abstract}
Patterns and causes of poverty and underdevelopment have shifted considerably over the last two decades. Growing global inequality within and between nations is now inextricably linked to both the exigencies and impacts of the global economy. In this article I argue that our universities, while developing students' core skills and competencies to work within this global economy, fall short in providing them with the contextual competencies to critically engage with the multi-faceted challenges posed by it. In other words, our universities are failing to produce critically engaged global citizens.

As universities opt to leave this contextual educational component to NGOs within the development sector - a sector with its own challenges and limitations - I go on to argue that global citizenship education as popularly promoted within this sector is also limited. In equating global citizenship and activism with consumerism, it depoliticises and individualises acts of engagement, thereby eroding the potential for collective, transformative action. I conclude by urging that, as teachers, mentors and public sociologists, we reclaim global citizenship as a collective project engaged in the political struggle for meaning and 'truth' within our classrooms and institutions.
\end{abstract}

Key words: globalisation; development education; global citizenship; consumerism; celebrity 


\section{Introduction}

Higher education institutions in Ireland, as elsewhere, are facing severe challenges on a number of fronts. While, on the one hand, increasing enrolment figures coupled with dwindling state support leaves them facing severe financial challenges, on the other, the very idea and fundamental role of higher education is being challenged through the shifting nature of knowledge(s) and the changing needs of an increasingly complex global society.

Of course, higher education has always been and remains a highly contested concept. From liberal conceptions derived from nineteenth century ideals of 'knowledge for its own sake' (Newman 1976) to the new language of the 'knowledge economy' emphasising competencies, enterprise, skills and outcomes (OECD 2004; Forfás 2007; NCC 2009; Department of Education and Skills 2011), debates on the role, quality and relevance of higher education continue apace. The exigencies of the contemporary globalised knowledge economy tend to favour a more vocational function for higher education, with its role now almost universally seen to lie in equipping students with the skills to work in and promote this global economy. Yet, despite being equipped to be employed within it, how well do our students and graduates understand the workings of this economy? How conversant are they with its social and political exigencies and effects? And, more to the point for us as teachers, mentors and sociologists, how well are we equipping our students to critically engage with, mediate and, if necessary, challenge the global system in which they live and work? 
In this article I argue that students and graduates are increasingly ill-equipped to comprehend and critically engage with the multi-faceted challenges posed by our contemporary, networked economy. The reason for this, I argue, is our persistent reliance on an outmoded, apolitical 'us' and 'them' dichotomy within our universities which relegates so-called 'development' or 'third world' issues to the margins of our teaching curricula as we concentrate on issues which affect 'us' and retain a stubborn myopia in relation to their complex, intertwined relationship with 'them'. I go on to argue that the dominant concept of development education or global citizenship education as promoted within the development sector - the sector through which many students gain some insight into this complex world - is also limited as, equating global citizenship and activism with consumerism, it depoliticises and individualises acts of engagement, thereby eroding the potential for collective transformative action. I develop my argument as follows.

In the following two sections I discuss the changing role of higher education in two respects. First, I examine its changing role in the context of the insertion of national economies into the global capitalist economy. Drawing briefly on my own work within the Democratic Republic of the Congo (DRC), I highlight the role of the global economy in fostering and consolidating poverty, insecurity and violence in the region. I also highlight the power of global networks of solidarity and activism in this regard. In the second section, drawing on the rich theoretical work of both educational theorist Ronald Barnett and critical theorist Robert Cox, I explore the thorny yet critical question as to what is 'higher' about higher education in this context, concluding that it as much about developing the skills, competencies and capacities to critically engage with the politics of the global economy as it is about securing the 
core competencies to operate within it. Within the challenging context of the corporatisation of higher education, I go on to argue that this poses a challenge to us as sociologists. I then go on in the third section to draw on the results of two surveys to highlight the prevalence of an apolitical, individualised 'us' and 'them' understanding of global inequality among Irish students. Drawing on relevant excerpts of the strategic plans of the seven universities in the Republic of Ireland together with their graduate attributes as available, I demonstrate how the survey findings mirror the conception and approach to global citizenship across the university system more broadly. The individualisation and commodification of the concepts of citizenship and activism within the development education sector is the focus of the fourth section leading on to my conclusion where I argue for a renewed focus on collective political activism and agency within our curricula in this context.

\section{Globalising economies, states, societies and education}

The story of the remarkable turnaround in the Irish economy during the 1990s and early 2000s has now been well rehearsed. While the causes of this transformation are still the subject of much debate, there is agreement that one key factor driving country's economic success was the proactive role played by the state in the attraction of almost 1,000 foreign-owned companies (MacSharry and White 2000; O'Riain 2004). While political stability coupled with a range of favourable tax incentives offered by the state combined to produce a climate attractive to this investment, a key contributing factor was also the high-level educational skills and knowledge base nurtured through a rapidly expanding higher education sector (Fitzgerald 2000). The influential strategy document produced in 1996 by Forfás, the policy advisory and 
coordination board for industrial development, science and technology, emphasised that the main determinant of the competitiveness of the enterprise sector was the skills and knowledge of the workforce. As White $(2000,192)$ notes, 'The [Forfás] report was indicative of how much the education system had become central to the success of the state's industrial policy'. Thus, higher education, with its role in advancing core knowledge, had come to serve as a key driver for Ireland's insertion into the global economy.

While certainly bringing significant opportunities and benefits to many, the congruence of economic globalisation with growing inequality is now well recognised. As Mittelman $(1996,18)$ notes in this context, 'life is marked by a deepening divide between rich and poor'. The specific case of the DRC, a country rich in natural resource wealth yet paradoxically, through the activities of a range of global networks (both legal and illegal) of extraction and accumulation, actually one of the world's poorest, serves as just one illustration of this trend. While the total mineral wealth of the DRC has been estimated at US\$ 24 trillion (Morgan, 2009), thereby making it potentially the most wealthy country in the world, it ranks among the poorest. Its gross national income is just $\$ 444$ per capita and it is ranked 186 out of 187 in the United Nations Human Development Index (UNDP, 2014, 166).

Why so? The explanation appears to lie in the global exploitation and expropriation of the country's wealth which, while benefitting a national and global elite, does so at the expense of the rights and well-being of the vast majority of Congolese citizens. A United Nations report on natural resource exploitation in the country is illuminating in this regard. The report cites 85 multinational corporations, many of whom are well- 
known reputable firms employing our own graduates - e.g. Barclays, De Beers, Anglo American - colluding with local criminal networks in resource extraction (UNSC, 2002, 7-10). With rebel forces backed by many of these corporations (in an ongoing resource war which, by 2007 had claimed an estimated 5.4 million lives (International Rescue Committee, 2007) with an estimated 2.6 million people remaining internally displaced as of $2013^{\mathrm{i}}$ ), retaining an armed stronghold on national resources, the DRC exemplifies the violently dislocating impact of the exigencies of the ever expanding yet ever demanding global economy. Yet, on the flip side, international collective action in collaboration with local actors also reveals the importance and efficacy of global collective activism on these issues. In Europe for example, pressure from 59 global activist groups which, in September 2013, called specifically on the European Commission to introduce legislation to stop global corporations' exploitation in the region, resulted in some regulation in this area with the introduction of a system of self-certification for companies earlier this year (March, 2014) ${ }^{\mathrm{ii}}$. Meanwhile in the US, pressure from global activist coalitions such as Global Witness or the Enough Project has led to a series of legal provisions which now require corporations to report on and provide evidence that their raw materials and supply chains are not linked to the Congolese conflict. The Congolese example, therefore, serves to illustrate both the negative and the positive effects of the global economy. While, on the one hand, the drive for profit at seemingly any cost is resulting in egregious levels of immiseration and violence for wide swathes of the country's population, on the other, and in reaction to this, this has given rise to global activist coalitions which, harnessing their collective power, have had and continue to have a significant transformative influence - on both policy makers and on citizens more widely. 
This section has set out to outline one of the fundamental contradictions in higher education today. While universities are key in promoting and fuelling the global economy, the evidence is now indisputable that the exigencies of this economy are contributing to growing inequality, poverty and, in many instances, violence. So where does this leave us as educators, teachers and mentors? What is the role of higher education in this context? In the following section I consider these questions in the context of broader educational theory and the role of public sociology in this regard.

\section{What is 'higher' about higher education?}

Accepting that higher education is a highly contested concept and posing the question 'what is higher about higher education?', educational theorist Ronald Barnett (1995, 25-27) argues that three irreducible characteristics remain at the core of higher education, however conceived. First, higher education is about building 'higher order' concepts and perspectives rather than the acquisition of low level facts and information. These 'higher order' concepts and perspectives, having built upon preceding concepts over time, offer explanatory frameworks for the lower level facts and information. Second, in the post-modern era where the universality of knowledge has been challenged and the search for the ultimate 'truth' abandoned, higher education has become about critical reflection and reflexivity. Thus, as Barnett puts it $(1995,27)$, 'there is no end point in thought and action, only conversation... and true conversation means taking seriously the critical viewpoints of others, perhaps even entering a different world held open by those others.' 
So how do these characteristics apply to the quality and relevance of learning within contemporary higher education institutions? According to Barnett $(1995,27)$ 'students on courses of higher education should be encouraged to enter into a continuing conversation, be prepared to take on the point of view of others and become comfortable in conducting that critical dialogue with themselves.'. Thus, students need to be supported and encouraged in developing faculties to critically mediate, negotiate, and critically engage with the increasingly complex world in which they live.

It is useful in this context to examine in more detail what is understood by and entailed in critical education at this important historic juncture. The work of Robert Cox is particularly apposite in the light of the globalised shifts within higher education. Cox's critical theory approach, first developed within his work in the field of International Relations (Cox 1981), emphasises the importance of standing outside the prevailing order and interrogating how this order came about, together with how and by whom it comes to be reproduced. In particular, Cox focuses on the nature and origins of institutions and their social relations, examining how these function and how they can change (Cox 1981, 88-89). Drawing on Cox's work, Dale and Robertson (2009) argue that a critical approach to contemporary education entails an engagement with the wider challenges posed by contemporary globalised, and globally driven, transformations. Specifically they argue $(2009,24)$ for a 'need to get beyond framings and analysis of education policymaking that continue to assume education to be a national enterprise taking place within what has historically been called the "education sector"'. This is because the persistent appearance of national 
autonomy serves to conceal the real sources of problems and power - with many of these extending far beyond national borders.

This is all complicated however by the increasing corporatisation of universities which, struggling with declining budgets and intensified competition, are responding with market-based solutions, moving them closer to the realm of private corporations than publicly engaged institutions. In this context Henry Giroux, a staunch opponent of such a move, identifies within the corporatist culture thus engendered 'an ensemble of ideological and institutional forces that function politically and pedagogically both to govern organisational life... and to produce compliant workers, depoliticised consumers and passive citizens' (Giroux, 1999, 148). This has particular resonance with respect to the concept of community engagement or citizenship promoted within universities in Ireland (see the following section) and Giroux's assertion that 'education must be treated as a public good and not merely as a site for commercial investment or for affirming a notion of the private good based exclusively on the fulfilment of individual needs' $(1999,151)$ is particularly apposite in this context.

Another sociologist concerned by this trend is Michael Buroway who, in his eloquent Presidential Address to the 2004 American Sociological Association, posed the following questions: 'Is the market the only solution? Do we have to abandon the very idea of the university as a "public" good?' (Buroway, 2005, 263). In this context, Buroway called for a renewed interest in a 'public sociology' - a sociology which moves outside the rigid confines of academia to engage with society in explicitly public and political ways. In this regard, as Buroway $(2005,263)$ notes, 'students are our first and captive public'. If we are to serve as public sociologists 
therefore, we need to move beyond traditional disciplinary and institutional confines (in a messy, complex world which knows no disciplinary boundaries) to engage in collective public debate and, where necessary, action with our students and with others, on contemporary global issues.

In short, higher education in a globalised era is not just about feeding and fuelling the global economy, it is about critically engaging with the politics of this global economy, either as individuals or collectively. In essence, higher education is about fostering critically engaged global citizenship. In the following section, I attempt to examine the extent to which this is taking place within Irish universities.

\section{Global Citizenship within Ireland's Universities}

While, given the dearth of data available, it is difficult to make any definitive assessment of the level of global citizenship education and activism within our universities, in this section I draw on two different sources in an attempt to explore this in more detail. First, I draw on two surveys of university students, conducted in 2006/7 and 2012 respectively, to examine both students' understandings of the causes of global inequality and their preferred forms of activism in this regard. Second, I explore the concepts and understandings of global citizenship or engagement as set out in the respective strategic plans of the seven universities in the Republic of Ireland as well as, where applicable, within their lists of graduate attributes.

Two surveys, both sponsored by Irish Aid and aimed at eliciting information on student attitudes towards development assistance broadly, were conducted in 2006/7 and 2012 respectively. The survey conducted in the academic year 2006/7 was 
conducted in a classroom setting across a range of academic departments and disciplines across the seven universities in the Republic of Ireland. A total of 900 useable surveys were taken and a gender balance was ensured. For our purposes here, two findings in particular are of interest. The first concerns students' understanding of the causes of global poverty ${ }^{\text {iii }}$. In a question asking students to rank, in order of importance, 14 different reasons (both internal and external) provided for poverty in developing countries, the top three reasons ranked as important or very important appear internal. These are, respectively, 'a lack of education and training' (96 per cent), 'corruption' (92 per cent), and 'war' (92 per cent) (Connolly, Doyle and Dwyer 2008, 220). The top ranked cause again appears in the following question which asks students to rank a set of judgement statements concerning poverty in developing countries. In a list of nine somewhat arbitrary judgement statements provided (the rationale for the statements is not provided and they do not all mirror the reasons provided in the previous question making a comparison thus difficult), the top three statements scoring an 'agree' or 'totally agree' rank are 'poverty in developing countries exists because they lack education and training' (91 per cent), 'the gap between the rich north and the poor south in the world is unacceptably large' (90 per cent), and 'the debts of developing countries must be abolished' (79 per cent). These findings indicate that the root of the issue appears to be a traditional view of lack of education within countries. However, the structural issue of debt (highlighted in Ireland through the high-profile work of the Debt and Development Coalition and the associated global Jubilee movement) is also highly ranked. Tellingly however, a statement that 'the wealth of the North is based on the poverty and exploitation of developing countries' attracts an 'agree' or 'totally agree' ranking from just 48 per 
cent of student respondents while 44 per cent either 'disagree' or 'totally disagree' with this statement (Connolly, Doyle and Dwyer 2008, 221).

The second issue of interest to us is students' views on how they themselves might make a difference. Two questions are of interest in this regard. The first asks 'how do you think you can help people in poorer countries' and provides nine options. This appears to be a tick box option and multiple options can be ticked. The three top scoring options reflect an individualistic, charity-based approach and are, respectively, 'buy fair trade goods' (63 per cent), 'contribute to charities' (61 per cent) and 'volunteer' (38 per cent) while the lowest ranked options reflect a more political, collective action approach and are 'sign a petition' (12 per cent), 'become involved in a church or campaigning groups' (15 per cent), and 'tourism or travel to a developing country' (16 percent) (Connolly, Doyle and Dwyer 2008, 225). These findings are somewhat mirrored in the following question which asks students to rank 'ways in which you can most effectively contribute to reducing poverty in developing countries'. The top first choice option by a significant amount is 'contribute to charity' (40 per cent), the second is 'pay taxes' ( 16 per cent) and 'buy fair trade' or 'work in a developing country' both come in at joint third (12 per cent each). In contrast, and somewhat contradicting the findings above, 'travel to a developing country as a tourist' gets 0 per cent of first choice preferences, while the more political options of 'become involved in church or campaigning groups' and 'support socially responsible businesses' attract just 2 and 4 per cent of first choice preferences respectively (Connolly, Doyle and Dwyer 2008, 225). Taken together, these findings appear to point towards both a prevalence of an 'us' and 'them' dichotomised understanding of the causes of underdevelopment (with the possible exception of the 
debt issue) and an individualised, charity based approach to its solution among Irish students. The findings appear to support the conclusion of the authors that 'there is little evidence of any sophisticated understanding of development issues, or any capacity to rank different explanations of development' $(2008,226)$ together with their observation that there is a need 'to focus more on creating a better understanding of the causes of underdevelopment and the structural factors relating to interactions between wealthy and poor states.' $(2008,209)$.

A second survey of third level students was carried out in 2012. This survey, again funded by Irish Aid, commissioned by the Development Education agency Suas and administered by the consultancy firm, Amárach Research, was an online survey of a sample of 1,000 students across both universities and Institutes of Technology (IT) with findings broken down by gender, age, social class, region and type of institution (university versus IT). Although a much broader survey than the previous, this recent survey included a number of questions which mirror those of the 2006 survey and are useful to our purposes. Again, of interest here are questions relating to student understandings of causes of underdevelopment and their preferences for activism. Within the former category, the top ranked preferences among university students in relation to a question on the reasons why some countries in the world are poor (from among a list of 20 provided) are 'corruption' (58 per cent), 'war/conflict' (56 per cent), and a 'lack of education' (46 per cent). Somewhat paradoxically, although the fourth highest ranked cause is 'better off countries taking advantage of poor countries' (at 43 per cent), the lowest ranked cause is 'international trade and economic policies' (25 per cent) (Suas, 2013, 7 - Table 2). These responses therefore show little 
difference in attitudes and understanding from those of the 2006 survey, with little apparent understanding of the globalised nature of poverty.

As with the 2006 survey, respondents were also asked to indicate levels of agreement or disagreement with a series of statements. The specific statements provided however (18 in total) did not mirror those of the 2006 survey. Of the statements provided, 85 per cent of university students agreed or strongly agreed with the statement that 'sustainable development can't happen without political, economical and structural change'. Eighty per cent agreed or strongly agreed that 'the actions of individuals can have repercussions in one own countries as on the other end of the planet', and 72 per cent agreed or strongly agreed that 'it is important to tackle poverty in the developing world because we belong to the same community'. The statements university respondents least strongly agree with are that 'the third world should deal with its own problems and not look to the first world for help' (13 per cent) and that 'making societies better is the responsibility of government agencies and/or NGOs, not mine' (18 per cent) (Suas, 2013, 12 - Table 5). These findings are particularly interesting in that they appear to contradict the findings in relation to understanding of causes of poverty in that they do indicate an awareness of global interconnectedness and an attendant collective responsibility to tackle global inequalities.

The 2012 survey also includes a question on global activism. In response to a question on the effectiveness of actions that Irish people can take to support developing countries, the top three ranked preferences among university students are, respectively, 'volunteering overseas' (81 per cent), 'volunteering to promote 
development' (77 per cent), and 'buying fair trade products' (74 per cent). At the other end of the scale, the lowest ranked preferences are 'lobbying the Irish government' (31 per cent), and 'taking part in a public meeting / demonstration' (38 per cent) (Suas, 2013, 19 - Table 8). These findings mirror those of six years previous in that they demonstrate a prevalence of an individualised, apolitical approach to activism with an emphasis on volunteering (a charity model) and consumerism as a way out of poverty. Overall, the findings of this most recent survey of university students appear broadly similar to those of the 2006 survey, although with one important (although slightly paradoxical) difference. Students surveyed most recently do indicate some awareness of the global interconnectedness within contemporary society and its structures although they strongly revert to individualised, charity-based approaches in tackling this. As Audrey Bryan, a development education specialist notes in a reflection on these findings, they indicate '...a lack of understanding about the importance of connecting with wider movements which seek to transform these [global] structures and the ideologies that support them. Rather many third level students seem to understand development as being primarily about helping less fortunate others...' (Suas, 2012, 8). Although any overall conclusions in relation to students' understandings of both causes of underdevelopment and their role as global citizens in this context must necessarily be tempered due to the dearth of longitudinal, systematic research in this area, the relevant findings from these two surveys do indicate a relatively poor understanding of the globalised roots of localised pockets of poverty, inequality, conflict and violence. Moreover, they strongly indicate an individualised, apolitical approach to activism in this area, with activism reduced to individual acts of charity and/or consumerism. From where do these attitudes and understandings emanate and what 
role do our universities play in this context? This is the subject of the following subsection.

Up to this point I have attempted to a) demonstrate the inextricable interconnectedness between increasing integration with the globalised capitalist economy and growing poverty, inequality, conflict and violence in many locations around the world, and b) the role of higher education in not just fuelling this economy with skilled graduates but also about fostering a critically engaged global citizenship among these same graduates. The survey results above indicate significant shortcomings in this latter endeavour. In an attempt to understand why this is so, I now explore the concepts and understandings of global citizenship or engagement as set out in the respective strategic plans of the seven universities in the Republic of Ireland as well as, where applicable, within their lists of graduate attributes. My assumption is that these institutional conceptualisations inform teaching and learning within these institutions, thereby influencing student and graduate attitudes and actions. While again, owing to the opacity and relative ambiguity of the language employed within these documents, this is necessarily an imprecise exercise, it does nonetheless highlight some interesting and illuminating overlaps with the findings from the survey research discussed above. The key concepts as employed within each university are examined in turn below (in alphabetical order).

\section{Dublin City University (DCU)}

DCU's Strategic Plan, entitled 'Transforming Lives and Societies' (2012-2017) includes a section on Graduate Attributes which it claims are 'integrated into all our degree programmes' (DCU, 2012, 21). These, it is asserted, 'aim to shape our 
students into adaptable, rounded individuals who are Creative and Enterprising, Solution-focussed, Effective Communicators, Globally-aware, and Active Leaders. (idem, emphasis added). While the Strategic Plan stops short of any further elaboration, the institution's website includes a dedicated section on these. Here the 'globally-aware' attribute (number four of six) is interchangeable with 'globallyengaged' and this is defined as follows: 'to value tolerance and cultural diversity, and to be committed to civic engagement ${ }^{\text {'iv }}$. Elsewhere again ${ }^{v}$ 'civic engagement' is described as comprising three elements - university-community dialogue; incentives and resources for educational growth and development in the wider community; and sustainability. Although the 'wider community' in this context is not specified, a global component is not explicitly noted. Global engagement or awareness therefore appears limited to personal values of tolerance (for the 'distant other') and respect, mixed with volunteerism.

\section{National University of Ireland Galway (NUIG)}

NUIG's Strategic Plan (2009-2014) asserts a commitment to 'a holistic educational and life experience' which fosters 'a wide range of life skills in our students, including vocational, sporting and cultural skills, by providing service learning and volunteering opportunities and through supported extra-curricular activities' (2009, 13). The Plan sets out eight aims for its undergraduate teaching (NUIG, 2009, 21-22). The fifth of these is the 'wholehearted commitment by staff and students to 'good citizenship' through active engagement in civil society'. There is, unfortunately, no further elaboration on what is meant by this 'good citizenship' and 'active engagement' although the University does once again note its commitment to 
volunteering and service-learning (NUIG, 2009, 24). The holism in learning appears closely linked with volunteerism here also therefore.

\section{National University of Ireland Maynooth (NUIM)}

The Strategic Plan of NUIM (2012-2017) speaks of 'a distinctive Maynooth model of liberal undergraduate education, forming graduates competent in their chosen disciplines, with the fundamental intellectual skills of analysis, reflection and critical thinking, and fostering an appreciation of the breadth and richness of human knowledge and culture' (NUIM, 2012, 11). Objective eight of the nine curricular objectives set out in the plan talks of 'service learning and civic engagement opportunities' again in the context of work-based learning. No further elaboration on this is provided.

\section{Trinity College Dublin (TCD)}

TCD's Strategic Plan (2014-2019) makes reference to both 'engaged citizenship' (TCD, 2014, 66) and 'volunteering, public service and civic engagement' (TCD, 2014,74 ) although no specific reference is made to global citizenship or global engagement in this context. Engaged citizenship includes the dissemination of research (through opinion pieces, media work, public expositions) as well as bringing 'major international thought-leaders to Ireland for public discussions'.

\section{University College Cork (UCC)}

UCC's Strategic Plan (2013-2017) - entitled 'Sustaining Excellence' and highlighting its role as an 'engaged university', has possibly the most to say in relation to global citizenship. Noting the University's commitment to 'adopting a global perspective in 
all of our activities' it asserts that 'the institution's pan-university Centre for Global Development provides a context in which we recognise that global challenges can only be addressed in collaboration between the developed and developing worlds.' (UCC, 2013, 6). What forms these collaborations take remains unexplored. However, civic engagement of the form highlighted within the other universities - i.e. volunteering - is also noted. 'Closer to home, we are actively engaged with our local community through staff and student partnerships and volunteering activities with a range of social and civil society organisations.' (UCC, 2013, 6).

\section{University College Dublin (UCD)}

UCD's Strategic Plan (2009-2014), interestingly entitled 'Forming Global Minds', makes explicit reference to the role of higher education within the global economy at the outset, strongly echoing the vocational role attributed to higher education as discussed earlier in this article. The Plan (UCD, 2009, 10) notes that

Ireland can and should lead the way in developing the higher-education system that produces the new graduates to create, adapt and thrive in the global economy. The universities are central to ensuring Ireland continues to advance this objective. Investing in universities means investing in new and more knowledge and innovation capacity, in the production of a competent and flexible labour force.

Within this framework UCD sets out three Graduate Attributes (UCD, 2009, 15), the third of which is 'globally engaged'. This includes 'an appreciation of the richness and diversity of human cultures... an awareness of his or her responsibility as a global citizen [this remains undeveloped]... and a commitment to equity, inclusion and diversity in his or her work and life context'.

\section{University of Limerick (UL)}


Finally, UL's Strategic Plan (2011-2015), which seeks 'to produce critical-thinking, creative, innovative and entrepreneurial graduates who will be leaders in society and will exhibit strong ethical, cultural and community-focused values.' (UL, 2011, 8), asserts that it will 'provide students with experiences that instill the spirit of European and global citizenship.' (idem). As elsewhere however, what precisely is meant by 'the spirit of European and global citizenship' is left to the reader's imagination. Elsewhere within the plan (UL, 2011, 14) reference is made to the 'social and cultural role of universities' (though not political), with universities seen to 'play a key role in 'the development of students as imaginative critical thinkers and socially responsible citizens.'. This theme of 'responsibility' again appears within the six Graduate Attributes ${ }^{\mathrm{vi}}$ where it is defined as:

Adopting a responsible, civically aware and engaged approach to their [students'] actions and decisions at work and in society; exploring issues of corporate and social responsibility, ethical practice and sustainability; adopting a global perspective, recognising both the local and global impact of decisions and actions; being personally and professionally responsible, orientated towards making substantial and positive contributions to society.

What is striking from this admittedly limited exercise which attempts to explore dominant conceptions of global engagement / citizenship / social responsibility across the university sector is the similarity between university conceptions and those of of students, as reflected in the two survey findings outlined above. Although in some cases reference is made to global interconnectedness and corporate responsibility, the overwhelming emphasis is on personal responsibility and volunteering. This echoes the conception of global citizenship promoted more broadly across the OECD - a conception which Jefferess (2008) critiques as a new form of imperialism which normalises the conditions of privilege which allow some to be in the position to help by defining the global citizen as one who helps an unfortunate 'Other'. With 
universities, enmeshed within global corporate networks, thus failing to challenge these conditions of privilege and produce critically and politically engaged global citizens, this task is being increasingly entrusted to the informal development education sector. In the following section I argue that this sector, with its own its own resource constraints and pressures ${ }^{\text {vii }}$, has its own limitations in this regard.

\section{Activism as consumerism: The Limits of Development Education}

I have already argued that our formal higher education system proves ill-equipped in preparing students to critically engage in the globalised world in which we live and operate. Given this scenario, increasing emphasis has been placed, by Irish Aid and a range of NGOs, on popularising 'development' issues more broadly through 'Development Education' (DE) or 'Global Citizenship Education' (GCE). Indeed, many third level institutions now have some form of student 'development' association, public debates on global issues are common, and organisations like Suas $^{\text {viii }}$ frequently run short (for example ten week) development courses. Given its relative importance to third level students therefore, in this section I examine this concept and its associated project more closely. My overall argument is that, while DE/GCE certainly has merit in highlighting the interconnectedness among people and global structures, as a tool for global political awareness and agency, it remains somewhat limited. This is because, in equating global citizenship and activism with consumerism, it depoliticises and individualises acts of engagement, thereby eroding the potential for collective transformative action. 
A good place to begin this argument is perhaps with an examination of different definitions of DE/GCE and what it means in action across a number of its principle proponents. We begin with a definition from Oxfam.

Global citizenship education aims to empower pupils to lead their own action. Along with the knowledge and values that they have gained from learning about global issues, pupils need to be equipped with the necessary skills to give them the ability and confidence to be pro-active in making a positive difference in the world.

Source: http://www.oxfam.org.uk/education/global-citizenship/what-is-globalcitizenship

Oxfam's target appears to be a somewhat younger generation (although the 'pupils' in question are not actually defined) and includes three main components - the acquisition of 'knowledge' and 'values' on global issues and also an action component.

Moving on to Trócaire, its target is also clearly a younger generation and their educators, and the emphasis is more on reflection and interaction on global connections - a more active form of knowledge acquisition, together with action.

Trócaire's Development Education work engages children, young people and educators through a process of interaction, reflection and action.... They are supported to make connections between their own lives and international social justice issues, and be empowered to make a positive difference in the world.

Source: http://www.trocaire.org/education/development-education 
Somewhat similarly, Irish Aid also talks about making connections but also stresses individual rights and responsibilities, proposing the purchase of Fair Trade products as one example of individual action that can be taken.

Making connections between how we live in Ireland and how this impacts on the lives of people in the developing world is at the heart of development education. Buying Fair-Trade products for example can make a real difference in the lives of producers in developing countries. Development education programmes provide an opportunity to challenge ourselves and find out more about our rights and responsibilities as global citizens contributing to change - act locally, think globally."

Source: https://www.irishaid.ie/what-we-do/how-our-aid-works/raisingdevelopment-awareness/

While these examples above are necessarily just a snapshot of the different framings and conceptions of DE/GCE among just three of its proponents, two common themes are already apparent. These are a) the focus on children/youth as a target of DE/GCE; and b) the focus on individual agency - in terms of both understanding and action. The focus on the younger generation may be simply reflective of the fact that much of the focus and resources of DE/GCE in Ireland is at primary and second level. The reasons for this remain unclear and, given it is now universally acknowledged that reflection, analysis and understanding (education) is a life-long process, certainly merit fuller investigation. This falls beyond the remit of this article however and, for now, I want to focus on the other striking aspect emerging from this brief review - the individualisation and, as we will see, increasing commodification of agency and action.

\section{Activism as consumerism: The commodification of agency}


One of the key distinctions between DE/GCE as an educational project and its more specialist, academic counterpart 'Development Studies' which also explores global interconnectedness, is the inclusion of a citizenship or action component in DE/GCE ${ }^{\mathrm{ix}}$. As we have seen within Irish Aid's definition as well as within student survey findings, one form of action proposed is the purchase of 'Fair Trade' products. Fair Trade has become increasingly popular in recent years. While certainly meritous in both drawing attention to inequities within the global trade system and reportedly guaranteeing a better price for producers, Fair Trade is somewhat problematic on that it reduces activism to (albeit reflective and discerning) consumerism. While no doubt assuaging some individual consciences, it fails to tackle the overall structural issues in the system. Moreover, its benefits to producers remain contested ${ }^{\mathrm{x}}$. The Fair Trade project is just one example of what might be regarded as the reconceptualisation of activism as consumerism. Other examples which move more into the charity model include the now ubiquitous 'global gifts' campaigns run by many development agencies at Christmas. A range of broader projects within this paradigm have now also gained considerable momentum - notably those attracting celebrity endorsement. This has given rise to the phenomenon characterised by Richey and Ponte (2011) as 'Brand Aid' - a combination of causes, branded products and celebrity. Possibly the most well-known example of this is 'Product Red' - an initiative created and launched by U2's Bono at the 2006 Davos World Economic Forum (where the irony appeared lost). Partnered with major global corporations such as American Express, Apple, The Gap and Starbucks, a range of products carrying the 'Product Red' insignia - from 'Beats' headphones to 'i-pad' cases to vodka ${ }^{\mathrm{xi}}$ are vigorously marketed (in the US in particular), with the 'Red' logo encouraging Western consumers to 'shop until it stops', 'it' being HIV/AIDS in Africa ${ }^{\text {xii }}$. 
While it is difficult, indeed churlish some might say, to criticise charity and seemingly well-meaning attempts to raise funds for essential development purposes, we need to think long and hard about the long-term impacts of such forms of agency and 'activism' on our understanding (and those of our students at whom such initiatives are primarily targeted) and 'ways of being' in the globalised world. The commodification of agency epitomised by the 'shopping to save the world' approach is symptomatic of the primacy of markets over social and political life. Difficult questions need to be asked as to whether such an approach can or will ever address the drivers of global inequality. It is important to be careful that, through our own actions, both as consumers and educators - as 'global citizens', we do not end up legitimising and reinforcing an inherently inequitable, exploitative and unsustainable system. As Danai Mupotsa, a PhD student following the phenomenon from South Africa, observes

I just don't buy the "buy, buy, buy" approach to making a better world. The "Africa" issue of Vanity Fair [a special issue produced in July 2007] is selfcongratulatory and problematic in my estimation. Yet, while I have a decided position on this campaign, as a young African feminist and scholar, finding the language to critically engage with Product Red and its implications has proved challenging.

(Himmelman and Mupotsa 2008, 2)

Analysing the celebritisation of advocacy and activism in Australia, April Biccum argues that rather than promoting a sense of political literacy, this new approach is narrowing the definitions of 'poverty' and 'development' and 'modelling a form of entrepreneuralised activism that promotes market-based solutions to development and is aimed at (re)producing neoliberal subjectivity’ (Biccum 2011, 1334). 
At a time when official aid flows are dwindling and private investment now accounts for over 80 per cent of all aid flows (Adelman 2009), we have indeed entered a blurred and increasingly blurry world where it can certainly be difficult, and indeed perhaps damaging, to engage too critically with contemporary trends. Yet, to put it bluntly, we are not going to be able to buy ourselves out of the mess that, through our global economic and political networks of accumulation and expropriation, we have created and continue to perpetuate. To suggest that we can is both intellectually lazy and politically irresponsible. To be clear, I am not arguing here that there is no place for ethnical consumerism, but I am arguing that this will not adequately tackle the global structural injustices created and reproduced through the global network economy which is, in part, fuelled by our own educational institutions. This begs the question where do we go to from here? With the atomisation and individualisation of agency promoted by contemporary DE/GCE campaigns, the challenges seem vast and a pathway out impossible. Yet, we need to remember (and to remind our students) of the different forms of agency, activism and citizenship possible. In this regard, the recent events of 2011 and beyond prove both inspiring and instructive.

\section{Beyond activism as consumerism: 'Networks of outrage and hope'}

Few can forget the momentous political events of 2011 where, beginning with the toppling of the dictatorship of Tunisia's Ben Ali in January and moving on to Egypt, the rest of the Arab world, Spain, London and New York, people mobilised to express their rejection of and outrage at the injustices meted out by governments placing their own interests, together with those of the global economic networks in which they were embedded, above the interests and rights of their citizens. Manuel Castells eloquently captured the moment when he described how collective movements of 
'ordinary' people moved the world from a darkened time of economic distress, political cynicism and personal hopelessness as they 'turned fear into outrage and outrage into hope for a better humanity' $(2012,3)$. Ireland also played host to such movements. In October 2011, the global Occupy movement spread to Dublin and on to Cork, Limerick, Galway, Waterford, Letterkenny and Athlone, opening up a much needed space for debate, deliberation and articulation of alternatives to the now discredited global system. And possibly the most powerful and inspiring example of all is the example set by the citizens of Ballyhea in North Cork who, bravely, zealously and literally marching against the consensual grain of Irish rural social life have, every Sunday since November 2011, marched in protest and anger at the bondholder bailing outs. As any Irish rural resident knows (this author included), such an act takes tremendous courage and determination. It demonstrates a solid courage of convictions and is all the more inspiring for it.

These real contemporary events are an important reminder that we are not limited or indeed isolated to the 'power of one' in our actions and activism - as implicitly promoted by DE/GCE proponents. There is no better time than this critical moment in global history to re-examine, through our teaching and curricula, what is meant by 'the political'. In this regard, given recent tumultuous global events, Chantal Mouffe's assertion $(2002,5)$ that '.. the political is from the outset concerned with collective forms of identification; the political always has to do with the formation of an 'Us"...' merits some reflection. Activism and citizenship is not an isolated, individual act. And, in a world where power is concentrated in globally networked chains of extraction and accumulation, a countervailing collective power is required. Bearing in mind that the fundamental power struggle in today's world is the struggle 
for meaning, understanding, and 'truth' in people's minds, it behoves us as teachers and public intellectuals to equip our students with the capacities to interrogate, critique, re-vision and re-imagine alternative and multiple meanings, understandings and 'truths'. At this critical juncture in our collective history (where the universal 'truths' of global prosperity, security and peace no longer hold), it is perhaps an opportune moment to reflect on what such a 'collective forms of identification' might mean in relation to our teaching, how they might be forged, and what role they might come to play in moving beyond consumer activism and shopping to save the world to a more transformative global citizenship as a way of meaningfully, critically and constructively engaging in our globalised world.

\section{Conclusion}

There can be no doubt that for us, as educators and as global citizens, we live in extremely challenging times. The evidence has mounted and is now indisputable that the global system in which we live, work and spend is not just economically unsustainable, it is also socially and politically so. If we are to take the consequences of this seriously and if we are to engage our students in doing so also, this demands profound changes in how we live our lives, how we relate to each other, how we relate to our structures of power and their representatives, and how we educate our students to operate in this context.

These challenges are all the greater because we are taking them on from institutions which are feeding and fuelling this globally dislocating system. With the waning and ultimate disappearance of the healthy and robust debates of the 1980s on vocationalism versus education as priority within higher education, the demand from 
higher education institutions today, as represented in in the media and in popular debate, is that we produce skilled yet intellectually sterile graduates ready for the global production line. As then Minister for Education and Skills (emphasis added) Ruairi Quinn, TD asserted earlier this year,

The third-level sector has made an enormous contribution to the challenges that this country has faced in the last number of years. Our highly skilled workforce is the key to increasing Ireland's competitiveness for foreign investment and for the growth of indigenous industries that will lead our country out of recession.

April 1 1t, 2014 - Address by Minister for Education and Skills, Ruairí Quinn T.D., at the USI Conference, Athlone - emphasis added.

As reflected here and as outlined earlier in this article, the dominant vision for higher education in contemporary Ireland, educational theory to the contrary, is to substitute critical enquiry for skills development; education with training; and active questioning and exploration with passive absorption and assimilation. As such, it forecloses the opportunities and imaginaries of students and graduates and it minimises our role as teachers and mentors.

If, as Mamdani in a somewhat different yet politically relevant context asserts, we are citizens and not subjects (Mamdani, 1996) - therefore active and not passive, we need to reclaim the concept of global citizenship within our institutions. We need to remind ourselves and our students that global citizenship entails critically interrogating the dominant narrative - always asking why. It entails acting accordingly - not as atomised, alienated individuals, but together, to collectively imagine, design and begin to build a more sustainable, just and equitable global 
society. And, most of all, it entails taking responsibility for our own actions and critically interrogating others, at all levels in politics and society, on theirs. 


\section{References}

Adelman, C. 2009. Global Philanthropy and Remittances: Reinventing Foreign Aid. Brown Journal of World Affairs 15(2): 23-33.

Barnett, R. 1995. Improving Higher Education - Total Quality Care. $2^{\text {nd }}$ ed.

Buckingham: The Society for Research into Higher Education and Open University Press.

Biccum, A. 2011. 'Marketing Development: Celebrity politics and the 'new' development advocacy', Third World Quarterly, 32(7), pp. 1331-1346.

Bryan, A. 2011. 'Another Cog in the Anti-Politics Machine?: The "De-Clawing" of Development Education', Policy and Practice: A Development Education Review, 12, pp. 1-14.

Buroway, M. 2005. '2004 American Sociological Association Presidential address: For public sociology', The British Journal of Sociology, 56(2), pp. 259-294.

Castells, M. 2012. Networks of Outrage and Hope: Social movements in the internet age. Cambridge: Polity.

Connolly, E., J. Doyle and F. Dwyer. 2008. Public opinion and development issues: A survey of Irish university student opinions. Irish Studies in International Affairs 19: 209-226.

Cox, R. 1981. Social Forces, States and World Orders: Beyond International Relations Theory, Journal of International Studies 10: 126-155.

Dale, R. and S.L. Robertson. 2009. Globalisation and Europeanisation in Education. Oxford: Symposium Books.

Delanty, G. 2001. Challenging knowledge: the university in the knowledge society. Buckingham: Open University Press \& SRHE.

Department of Education and Skills, 2011. National Strategy for Higher Education to 2030. Dublin: Government publications.

DCU, 2012. Transforming Lives and Societies: Strategic Plan 2012-2017. Dublin: Dublin City University.

Fitzgerald, J. 2000. The Story of Ireland's Failure - and Belated Success. In B. Nolan, P.J. O'Connell and C.T. Whelan (Eds.). Bust to Boom? The Irish Experience of Growth and Inequality. Dublin: Institute of Public Administration.

Forfás. 2007. Promoting Enterprise-Higher Education Relationships. Dublin: Forfás and the Advisory Council for Science, Technology and Innovation.

Giroux, H.A. 1999 'Vocationalising Higher Education: Schooling and the Politics of Corporate Culture' College Literature, 26(3), pp. 147-161. 
Himmelman, N. and D. Mupotsa. 2008. '(Product) Red: (re-)Branding Africa', The Journal of Pan African Studies, 2(6), pp.1-13.

IRC 2007. Mortality in the Democratic Republic of the Congo: An ongoing crisis, International Crisis Committee, available from http://www.rescue.org/sites/default/files/resource-file/20067_congoMortalitySurvey.pdf, accessed September $16^{\text {th }}, 2014$.

Jefferess, D. 2008. 'Global Citizenship and the cultural politics of benevolence', Critical Literacy: Theory and Practices, 2(1), pp. 27-36.

MacSharry, R. and P. White. 2000. The Making of the Celtic Tiger: The Inside Story of Ireland's Boom Economy. Dublin: Mercier Press.

Mamdani, M. 1996. Citizen and Subject: Contemporary Africa and the Legacy of Late Colonialism. Indiana: Indiana University Press.

McCloskey, S. 2011. 'Rising to the Challenge: Development Education, NGOs and Urgent Need for Social Change, Policy and Practice: A Development Education Review, 12, pp. 32-46.

Mittelman, J.H. 1996. Globalization: Critical Reflections. Boulder CO: Lynne Rienner Publications.

Moberg, M. 2014 'Certification and Neoliberal Governance: Moral Economies of Fair Trade in the Eastern Caribbean'. American Anthropologist, 116(1), pp. 8-22.

Morgan, M. J. 2009. 'DR Congo's \$24 trillion fortune'. African Business Magazine, February $1^{\text {st }}, 2009$.

Mouffe, C. 2002. Politics and Passions: the stakes of democracy. London: Centre for the Study of Democracy.

NCC. 2009. Statement on Education and Training (February 2009). Dublin: National Competitiveness Council.

Newman, J. 1976. The Idea of a University. Oxford: Oxford University Press.

OECD. 2004. Review of National Policies for Education: Review of higher education in Ireland. Paris: Organisation for Economic Co-operation and Development.

O'Riain, S. 2004. The Politics of High Tech Growth: Developmental Network States in the Global Economy. Cambridge: Cambridge University Press.

Richey, L.A., and S. Ponte. 2011. Brand Aid: Shopping Well to Save the World. Minneapolis: University of Minnesota Press. 
Storey, A. 2011. 'One World: Why Irish Development Educators should court controversy at home', Policy and Practice: A Development Education Review, 12, pp. 80-86.

Suas. 2013. National Survey of Third Level Students on Global Development: Report, January 2013. Dublin: Suas.

Suas. 2012. National Survey of Third Level Students on Global Development: Key Findings. Dublin: Suas.

TCD. 2014. Strategic Plan 2014-2019. Dublin: Trinity College Dublin.

UCC. 2013. Strategic Plan 2013-2017. Cork: University College Cork.

UCD. 2009. Forming Global Minds: Strategic Plan 2009-2014. Dublin: University College Dublin.

UL. 2011. Strategic Plan 2011-2015. Limerick: University of Limerick.

UNDP. 2014. Human Development Report: Sustaining Human Progress: Reducing Vulnerabilities and Building Resilience, United Nations Development Programme, New York: Oxford University Press.

UNSC. 2002. Report of the Panel of Experts on the Illegal Exploitation of Natural Resources and Other Forms of Wealth of the Democratic Republic of the Congo, United Nations Security Council, http://www.srwolf.com/reports/UNCONGO.pdf, accessed July $1^{\text {st }}, 2014$.

White, T. 2000. Investing in People: Higher Education in Ireland from 1960 to 2000. Dublin: Institute of Public Administration.

Williams, M. 2013. 'Alternative production and consumption relations?: Fair trade, the state, and cooperatives in the global South' Journal of Contemporary African Studies, 31(1), pp.1-17.

\footnotetext{
${ }^{\mathrm{i}}$ http://www.unhcr.org/pages/49e45c366.html, accessed September 12th, 2014.

ii See, http://business-humanrights.org/en/conflict-peace/conflict-minerals/proposed-eu-regulation-onconflict-minerals-commentaries-media-coverage, for example for an overview of the global campaign and various reactions to the recently introduced provisions. Accessed November 20th, 2014.

iii Presumably reflecting Irish Aid's focus on poverty as opposed to inequality/distribution, the survey questions are framed in terms of poverty in developing countries.

iv See https://www4.dcu.ie/node/44065, accessed November 21 ${ }^{\text {st }}, 2014$.

${ }^{v}$ See http://www4.dcu.ie/community/civicEngagement/engagementDCU.shtml, accessed November $21^{\text {st }}, 2014$.

${ }^{v i}$ See http://www2.ul.ie/pdf/982103103.pdf, accessed November $21^{\text {st }}, 2014$.

vii With the Irish development education sector coming under increasing funding pressures, some commentators (see for example Bryan, 2011) are questioning the extent to which has departed from its more radical roots. Specifically, both Storey (2011) and McCloskey (2011) are highly critical of the politically detached stance of much of the sector in relation to the 'global development' issues now on our doorstep in Ireland - e.g. the implications of IMF conditionalities and the social and environmental impacts of multinational investment.

viii See http://www.suas.ie/, accessed September 14 $4^{\text {th }}, 2014$.
} 
ix I am grateful to Eilish Dillon, Kimmage Studies Development Centre, for helping clarify this point. ${ }^{x}$ Fair Trade argues that it benefits farmers by providing better prices, decent working conditions, local sustainability, and fair terms of trade (see http://www.fairtrade.ie/what_is_fairtrade/faqs.html\#Q1) yet the few academic studies conducted in the area have failed to uncover any empirical evidence for this claim (see, for example, Moberg 2014; Williams 2013).

${ }^{x i}$ See http://www.red.org/en/shop, accessed September $14^{\text {th }}, 2014$.

xii A percentage of profits from the sale of 'Red' goods goes to the Global Fund for HIV/AIDS. 